\title{
Abundance of sucking insect pests on some flowering plants in relation to weather parameters
}

\author{
M. R. Amin ${ }^{1 *}$, M. A. Islam ${ }^{1}$, M. Afroz ${ }^{1}$ and S. J. Suh ${ }^{2}$ \\ ${ }^{1}$ Department of Entomology, Bangabandhu Sheikh Mujibur Rahman Agricultural University, Gazipur, Bangladesh \\ ${ }^{2}$ School of Applied Biology, Kyungpook National University, Daegu, Korea
}

Received: 02 June 2021

Revised: 24 August 2021

Accepted: 13 September 2021

DOI: https://doi.org/10.3329/bjsir.v56i4.57195

\begin{abstract}
The study was conducted from November 2017 to May 2018 in the experimental field at Gazipur, Bangladesh to investigate the incidence of sucking pests namely gladiolus thrips Teniothrips simplex, tuberose aphid Aphis craccivora, marigold aphid Neotoxoptera oliveri, and dahlia mealybug Plannococcus citri on their cultivated host plants in relation to temperature, relative humidity and rainfall. Results showed that the abundance of gladiolus thrips, tuberose aphid, marigold aphid and dahlia mealy bug reached the peak in the $3^{\text {rd }}$ week of January, $3^{\text {rd }}$ week of February, $1^{\text {st }}$ week of January and $1^{\text {st }}$ week of February, respectively. Among the weather factors, temperature had significant negative impact on the abundance of gladiolus thrips, marigold aphid and tuberose aphid, whereas rainfall showed significant negative influence only on marigold aphid. Multiple linear regression analysis showed that weather variables collectively predicted $55.9 \%, 75.9 \%, 44.5 \%$, and $34.6 \%$ abundances of gladiolus thrips, marigold aphid, tuberose aphid and dahlia mealybug, respectively.
\end{abstract}

Keywords: Aphid; Dahlia; Gladiolus; Marigold; Mealybug; Thrips; Tuberose; Weather

\section{Introduction}

Commercial flower production in Bangladesh was started firstly in Jhikargacha Upazila of Jashore district in 1970 and expanded to different areas in 1980 (Sultana, 2003). Nowadays, flower production and business is a popular agricultural enterprise in Bangladesh. The major flower and ornamental plant production belts in Bangladesh are Jashore, Chattagram, Cox's Bazar, Bogura, Gazipur, Mymensingh, Narsingdi, Rangpur, Khulna, Bandarban, Khagrachori and Rangamati (Reza, 2013). However, to satisfy national demand, various flowers, such as chrysanthemum, tuberose and gladiolus have been imported from India, and orchids, gerbera, anthurium and Thai rose rom Thailand every year.

Widely cultivated flowers in Bangladesh are roses, tuberoses, marigolds and gladiolas which supply about $90 \%$ revenue of total flower industries of the country (Reza, 2013). Flower production in Bangladesh is expanding day by day but the farmers are facing severe problems of the infestation of insects. Ali et al. (2016) reported that a total of 16 insect pests cause damage to flowers in Bangladesh. Islam et al. (2019) found that 51 insect species attack different ornamental plants in Bangladesh of which rose thrips, rose aphid, rose scale, rose budworm, tuberose aphid, tuberose bud borer, gladiolus thrips, thuja bagworm, marigold aphid, marigold ealybug and dahlia mealybug are the major pests.

The sucking insects namely thrips, aphid, scale insect and mealybug ingest sap from the leaves and flowers of ornamental plants using their mouthparts and cause damage. Both the nymph and adult stages of the sucking insects are harmful to plants. Their infestation causes deformities and discoloration of flowers. Infested plants suffer from normal growth and vigor, and show ellowing and stunting appearance. 
The sucking insects act as the primary vectors of virus diseases of plants and their excreted honeydews block light and air penetration in the infested leaves and so inhibit photosynthesis (Amin et al., 2016; Amin et al., 2017).

The sucking insects thrips are widespread and major pests of gladiolus (Pal and Sarkar, 2009). Aphids are common insect pests of tube rose (Blackman and Eastop, 2000), and they can build up population very rapidly on marigold (Piron, 2010). Mealybug occurs almost worldwide and deleterious to dahlia (Cox, 1989).

Weather parameters influence the perfection of insect population dynamics (Amin et al., 2018; Amin et al., 2019). So, it is important to acquire information on abundance and population dynamics of any insect pest regarding to meteorological parameters prior to develop its integrated management program. Therefore, the study was carried out to know the incidence of the sucking insects viz., gladiolus thrips Teniothrips simplex (Thysanoptera: Thripidae), marigold aphid Neotoxoptera oliveri (Hemiptera: Aphididae), tuberose aphid Aphis craccivora (Hemiptera: Aphididae) and dahlia mealybug Plannococcus citri (Hemiptera: Pseudococcidae) on their cultivated host plants. The study also assessed the impact of the meteorological parameters on the population build up of the insects.

\section{Materials and methods}

\section{Study site and conditions}

This study was conducted in a flower garden, and laboratory of the Department of Entomology of Bangabandhu Sheikh Mujibur Rahman Agricultural University (BSMRAU), Gazipur $\left(25^{\circ} 25^{\prime} \mathrm{N}\right.$ and $\left.89^{\circ} 5^{\prime} \mathrm{E}\right)$ from November 2017 to May 2018. The area has annual average temperature, relative humidity and rainfall of $25.8^{\circ} \mathrm{C}, 67 \%$, and $2036 \mathrm{~mm}$, respectively (Amin et al., 2015).

\section{Selection and management of ornamental plants}

Fifteen plants for each of gladiolus, tuberose, marigold and dahlia were selected from the garden and the plants were numbered with tags. Fertilizers were applied according to the Fertilizer Recommendation Guide
(FRG, 2012). Irrigation, weeding and stacking were done whenever needed, and the plants were grown avoiding management of sucking insects.

\section{Observation of the abundance of sucking insects}

The flower garden was monitored regularly to observe the incidences of thrips on gladiolus, aphid on tuberose and marigold, and mealybug on dahlia. Data were collected fortnightly from the advent of the pests and continued till their occurrences. Visual observation was done using hand lens. To collect data of the incidence of gladiolus thrips, five flowers were randomly selected on every observation day, and the number of nymphs and adults of thrips on each flower was counted. Data of the abundances of tuberose aphid, marigold aphid and dahlia mealybug were collected by observing the apical leaves of the plants. In every observation day five leaves were randomly selected for each of the plants, and the number of nymph and adult insects on each leaf was counted.

\section{Collection of weather data}

Data on temperature, relative humidity and rainfall were collected from the weather station of BSMRAU located $150 \mathrm{~m}$ away from the garden and are presented as figure 1 .

Data analysis

Pearson correlation and multiple regression model were determined along with the abundances of the insects and meteorological parameters. All the analyses were performed using IBM SPSS 20.0.

\section{Results and discussion}

Incidence of the sucking insect pests on different flowering plants during the study is presented in figure 2 . Results revealed that the gladiolus thrips showed their abundances from $2^{\text {nd }}$ week of November with mean abundance of $0.8 /$ flower and reached to the peak abundance (7.2/flower) in the $3^{\text {rd }}$ week of January when temperature and relative humidity were $16^{\circ} \mathrm{C}$ and $89 \%$, respectively, and there was no rainfall. Occurrence of thrips on gladiolus was found till $1^{\text {st }}$ week of March, when the mean abundance was $0.6 /$ flower. The findings revealed that the thrips had fluctuation of their abundances and their incidences were comparatively high 


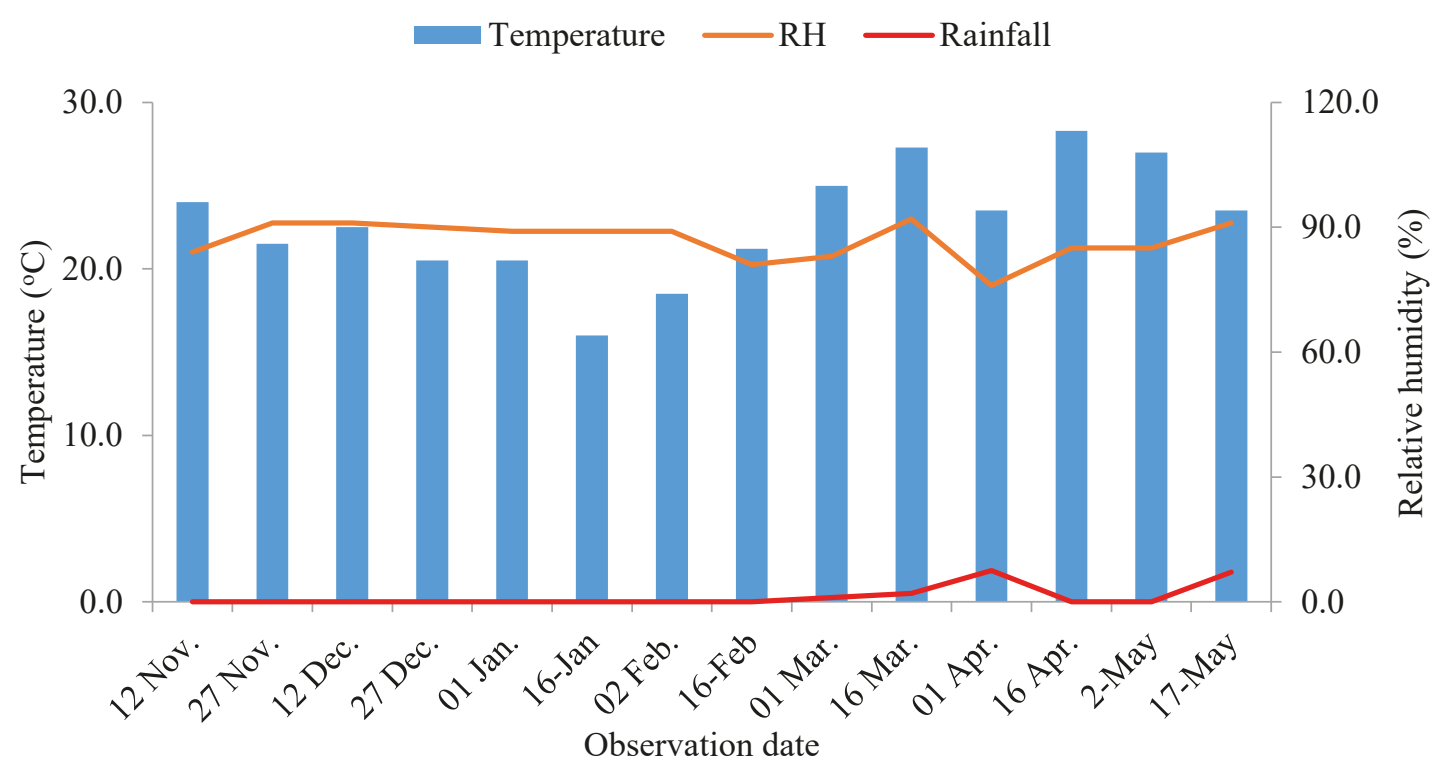

Fig. 1. Distribution of weather parameters during November 2017 to May 2018 at Gazipur in Bangladesh

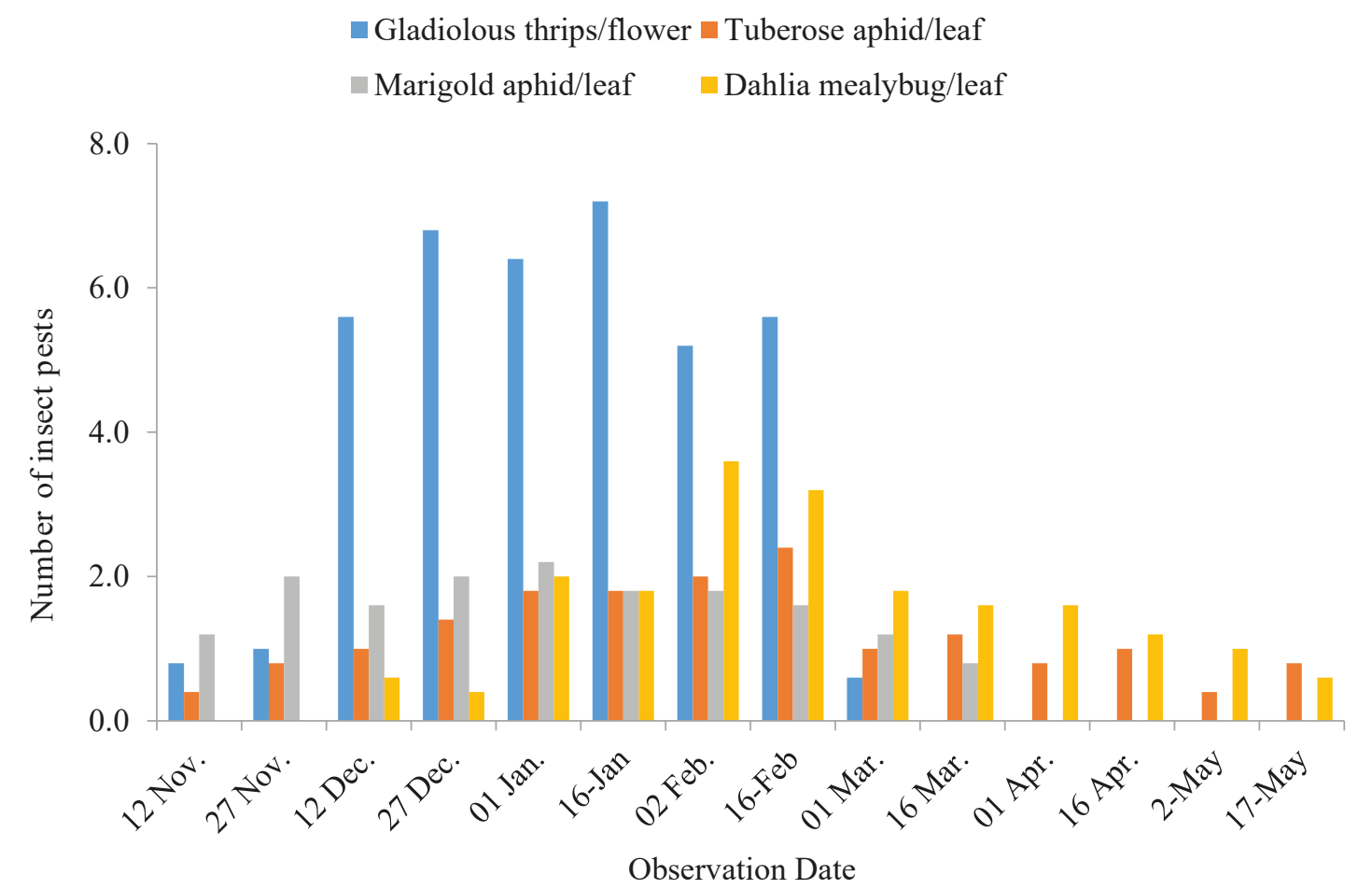

Fig. 2. Abundance of sucking insects on the flowering plants during November 2017 to May 2018 
during the winter season. Saiyad (2015) reported the population of gladiolus thrips decreased with increasing temperature and relative humidity.

Abundances of aphids on marigold and tuberose were found from $2^{\text {nd }}$ week of November and continued until $3^{\text {rd }}$ week of March on marigold and $3^{\text {rd }}$ week of May on tuberose. At the beginning their abundances on marigold and tuberose were 1.2/leaf and 0.4/leaf, respectively. The peak abundances of aphids on marigold (2.2/leaf) and tuberose (2.4/leaf) were found in the $1^{\text {st }}$ week of January and $3^{\text {rd }}$ week of February, respectively. Temperature and relative humidity were $20.5^{\circ} \mathrm{C}$ and $89 \%$, respectively in the peak period of aphid on marigold. At the peak period of aphid on tuberose temperature and relative humidity were $21.2^{\circ} \mathrm{C}$ and $81 \%$, respectively. There was no rainfall at the peak period of aphid on of the two flowering plants. The findings of the present study showed that the aphids revealed fluctuations of their population on both the flowering plants. They showed comparatively high population from $1^{\text {st }}$ week of January to $1^{\text {st }}$ week of February, when temperature was low and there was no rainfall. At that time the plants were also in juvenile stages. Dhaliwal and Arora (2001) stated the incidence, growth and multiplication of aphid are largely influenced by meteorological parameters like temperature, relative humidity, rainfall, wind speed and cloudiness. Abundance and distribution of herbivore insects vary with topography, existing host plants and natural enemies, and climatic conditions of the area. Ahmad and Kumar (2018) reported higher abundance of aphid A. craccivora on Vigna mungo and $V$. radiata in Bihar, India during $1^{\text {st }}$ to $3^{\text {rd }}$ week of December when temperature and relative humidity were $10.5^{\circ} \mathrm{C}$ to $16.9^{\circ} \mathrm{C}$ and $51 \%$ to $72 \%$, respectively. Reddy and Kumar (2004) reported the peak population of the aphid species Aphis gossypii and Myzus persicae on tomato during November and February in Karnataka, India.

Occurrence of mealybug on dahlia was found from $2^{\text {nd }}$ week of December to $3^{\text {rd }}$ week of May. The highest abundance of mealybug (3.6/leaf) was observed in the $1^{\text {st }}$ week of February, when temperature and relative humidity were $18.5^{\circ} \mathrm{C}$ and $89.0 \%$, respectively, and there was no rainfall. The findings showed that the mealybug exerted fluctuation of its population on dahlia and the peak occurrence was found in early February when the plants were at flowering stage and temperature was low (Figure 2).

Temperature and rainfall showed negative correlation with the abundances of the sucking insects on the studied flowering plants (Table I). Significant negative relationships of temperatures were found with the abundances of gladiolus thrips, marigold aphid and tuberose aphid. Abundance of dahlia mealybug was negatively correlated with the meteorological factors but the effects of the weather parameters were insignificant. The results coincided with Katke (2008) who reported that the

Table I. Correlation coefficient ( $r$ ) values between sucking insect population on different flowering plants and weather parameters

\begin{tabular}{lccc}
\hline & Temperature $\left({ }^{\circ} \mathrm{C}\right)$ & Relative humidity $(\%)$ & Rainfall $(\mathrm{mm})$ \\
\hline Gladiolus thrips & $-0.735^{*}$ & $0.384^{\mathrm{NS}}$ & $-0.514^{\mathrm{NS}}$ \\
Marigold aphid & $-0.770^{*}$ & $0.228^{\mathrm{NS}}$ & $-0.777^{*}$ \\
Tuberose aphid & $-0.633^{*}$ & $0.082^{\mathrm{NS}}$ & $-0.294^{\mathrm{NS}}$ \\
Dahlia mealybug & $-0.380^{\mathrm{NS}}$ & $-0.280^{\mathrm{NS}}$ & $-0.237^{\mathrm{NS}}$ \\
Temperature $\left({ }^{\circ} \mathrm{C}\right)$ & & $-0.213^{\mathrm{NS}}$ & $0.181^{\mathrm{NS}}$ \\
Relative humidity (\%) & & & $-0.286^{\mathrm{NS}}$ \\
\hline
\end{tabular}


Table II. Multiple regression models along with coefficients of determination $\left(R^{2}\right)$ regarding the impact of weather parameters on the seasonal abundance of gladiolus thrips during November 2017 to March 2018

\begin{tabular}{|c|c|c|c|c|c|}
\hline Regression equation & $\mathrm{R}^{2}$ & $100 \mathrm{R}^{2}$ & $\begin{array}{l}\% \text { Role of } \\
\text { individual } \\
\text { factor }\end{array}$ & F statistic & \\
\hline$Y=19.951-0.740 X_{1}$ & 0.540 & 54.0 & 54.0 & $\mathrm{~F}_{1,7}=8.2$ & $\mathrm{P}<0.05$ \\
\hline$Y=17.806-0.727 X_{1}+0.021 X_{2}$ & 0.541 & 54.1 & 0.1 & $\mathrm{~F}_{2,6}=3.5$ & $\mathrm{P}=0.09$ \\
\hline $\mathrm{Y}=20.042-0.071 \mathrm{X}_{1}-0.245 \mathrm{X}_{2}+0.294 \mathrm{X}_{3}$ & 0.559 & 55.9 & 1.8 & $\mathrm{~F}_{3,5}=2.1$ & $\mathrm{P}=0.22$ \\
\hline
\end{tabular}

$\mathrm{Y}=$ thrips population $/$ leaf, $\mathrm{X}_{1}=$ temperature $\left({ }^{\circ} \mathrm{C}\right), \mathrm{X}_{2}=$ relative humidity $(\%), \mathrm{X}_{3}=$ rainfall $(\mathrm{mm})$

Table III. Multiple regression models along with coefficients of determination $\left(R^{2}\right)$ regarding the impact of weather parameters on the seasonal abundance of marigold aphid during November 2017 to March 2018

\begin{tabular}{|c|c|c|c|c|c|}
\hline Regression equation & $\mathrm{R}^{2}$ & $100 \mathrm{R}^{2}$ & $\begin{array}{l}\% \text { Role of } \\
\text { individual } \\
\text { factor }\end{array}$ & F statistic & \\
\hline$Y=3.876-0.104 X_{1}$ & 0.592 & 59.2 & 59.2 & $\mathrm{~F}_{1,8}=11.6$ & $\mathrm{P}<0.01$ \\
\hline $\mathrm{Y}=2.255-0.102 \mathrm{X}_{1}+0.018 \mathrm{X}_{2}$ & 0.617 & 61.7 & 2.5 & $\mathrm{~F}_{2,7}=5.6$ & $\mathrm{P}<0.05$ \\
\hline$Y=-0.215-0.041 X_{1}+0.032 X_{2}-0.382 X_{3}$ & 0.759 & 75.9 & 14.2 & $\mathrm{~F}_{3,6}=6.3$ & $\mathrm{P}<0.05$ \\
\hline
\end{tabular}

$\mathrm{Y}=$ aphid population $/$ leaf, $\mathrm{X}_{1}=$ temperature $\left({ }^{\circ} \mathrm{C}\right), \mathrm{X}_{2}=$ relative humidity $(\%), \mathrm{X}_{3}=$ rainfall $(\mathrm{mm})$.

weather parameters did not show any significant relationship with the mealybug population on grape.

Multiple linear regression analysis showed that the effects of temperature, relative humidity and rainfall on the incidence of thrips on gladiolus were 54.0, 0.1 and $1.8 \%$, respectively (Table II). The weather factors collectively predicted $55.9 \%$ incidence of thrips on gladiolus and the result was insignificant. Single effect of tempera- ture, relative humidity and rainfall on the incidence of aphid on marigold was 59.2, 2.5 and $14.2 \%$, respectively, and the collective effect of the weather parameters $(75.9 \%)$ was statistically significant (Table III). Temperature, relative humidity and rainfall individually predicted 40.0, 0.3 and $4.2 \%$ incidences of aphid on tuberose and their combined effect (44.5\%) was statistically insignificant (Table IV). 
Table IV. Multiple regression models along with coefficients of determination $\left(R^{2}\right)$ regarding the impact of weather parameters on the seasonal abundance of tuberose aphid during November 2017 to March 2018

\begin{tabular}{llllll}
\hline Regression equation & $\mathrm{R}^{2}$ & $100 \mathrm{R}^{2}$ & $\begin{array}{l}\text { \%Role of } \\
\text { individual } \\
\text { factor }\end{array}$ & F statistic & \\
& \multicolumn{7}{c}{${ }^{2}$} & & & \\
\hline $\mathrm{Y}=3.718-0.110 \mathrm{X}_{1}$ & 0.400 & 40.0 & 40.0 & $\mathrm{~F}_{1,12}=8.00$ & $\mathrm{P}<0.05$ \\
$\mathrm{Y}=1.904+2.816 \mathrm{X}_{1}+4.720 \mathrm{X}_{2}$ & 0.403 & 40.3 & 0.3 & $\mathrm{~F}_{2,11}=3.7$ & $\mathrm{P}=0.05$ \\
$\mathrm{Y}=4.962-0.108 \mathrm{X}_{1}-0.104 \mathrm{X}_{2}-0.049 \mathrm{X}_{3}$ & 0.445 & 44.5 & 4.2 & $\mathrm{~F}_{3,10}=2.6$ & $\mathrm{P}=0.10$ \\
\hline
\end{tabular}

$\mathrm{Y}=$ aphid population /leaf, $\mathrm{X}_{1}=$ temperature $\left({ }^{\circ} \mathrm{C}\right), \mathrm{X}_{2}=$ relative humidity $(\%), \mathrm{X}_{3}=$ rainfall $(\mathrm{mm})$

Table V. Multiple regression models along with coefficients of determination $\left(R^{2}\right)$ regarding the impact of weather parameters on the seasonal abundance of dahlia mealybug during November 2017 to March 2018

\begin{tabular}{|c|c|c|c|c|c|}
\hline Regression equation & $\mathrm{R}^{2}$ & $100 \mathrm{R}^{2}$ & $\%$ Role of & \multicolumn{2}{|c|}{ F statistic } \\
\hline $\mathrm{Y}=3.924-0.101 \mathrm{X}_{1}$ & 0.144 & 14.4 & 14.4 & $\mathrm{~F}_{1,10}=1.7$ & $\mathrm{P}=0.22$ \\
\hline$Y=10.702-0.118 X_{1}-0.074 X_{2}$ & 0.270 & 27.0 & 12.6 & $\mathrm{~F}_{2,9}=1.7$ & $P=0.24$ \\
\hline$Y=11.994-0.108 X_{1}-0.089 X_{2}-0.103 X_{3}$ & 0.346 & 34.6 & 7.6 & $\mathrm{~F}_{3,8}=1.4$ & $\mathrm{P}=0.31$ \\
\hline
\end{tabular}

Table V showed that the single effect of temperature, relative humidity and rainfall on the incidence of mealybug on dahlia was $14.4,12.6$ and $7.6 \%$, respectively, and the collective effect of the weather parameters $(34.6 \%)$ was statistically insignificant. Weather parameters predict varied levels of influence on phytophagous insects and affect their population dynamics in the current and next generations. Many authors reported varied levels of the impact of weather parameters on the incidences of sucking insects on crop plants (Sharma and Singh, 2012; Namni et al., 2017; Mandal et al., 2018; Mohammad et al., 2019).

The present study investigated the abundance of different sucking insect pests on flowering plants and the impact of weather factors on their abundance. According to the findings, temperature, relative humidity and rainfall influenced the abundance of gladiolus thrips, tuberose aphid, marigold aphid and dahlia mealybug on the associated host plants. Among the weather factors, temperature can be described as the major factor contributing to the abundance of all of these four insect pests. The findings may be helpful to growers for selection of proper flower cultivation time to avoid the severity of infestation caused by these insect pests and for timely implementation of integrated pest management program.

\section{Acknowledgement}

The study was funded by the NATP-2, PIU, BARC, to whom the authors are very grateful. 


\section{References}

Ahmad E and Kumar S (2018), Seasonal incidence of Aphis craccivora Koch on Vigna mungo and Vigna radiata with its predator Cheilomenes sexmaculata (Fabricius) (Coleoptera: Coccinellidae), Adv. Agril. Sci. 6: 26-33.

Ali MR, Chowdhury MS, Karim MA, Hossain MMA and Mustafi BAA (2016), Pest risk analysis of cut flower and foliages in Bangladesh, Strengthening Phytosanitary Capacity in Bangladesh Project, Khamarbari, Farmgate, Dhaka-1205.

Amin MR, Afrin R, Alam MZ, Hossain MM and Kwon YJ (2017), Effect of leaf trichomes and meteorological parameters on population dynamics of aphid and jassid in cotton, Bangladesh J. Agril. Res. 42: 13-25. DOI: https://doi.org/10.3329/bjar.v42i1.31969

Amin MR, Afrin R, Suh SJ and Kwon YJ (2016), Infestation of sucking insect pests on five cotton cultivars and their impacts on varietal agronomic traits, biochemical contents, yield and quality, SAARC J. Agric. 14: 11-23. DOI: https://doi.org/10.3329/sja.v14i1.29572

Amin MR, Khisa S, Rahman H, Jannat $\mathrm{R}$ and Badruzzaman M (2019), Seasonal abundance of major sucking and chewing insects of guava, Bangladesh J. Zool. 47: 97-105.

Amin MR, Mia MR, Rahman H, Miah MG and Ge F (2018), Insect community in agroforestry: role of weather parameters on population dynamics, Indian J. Ecol. 45: 88-92.

Amin MR, Namni S, Miah MRU, Miah MG, Zakaria M, Suh SJ and Kwon YJ (2015), Insect inventories in a mango-based agroforestry area in Bangladesh: foraging behavior and performance of pollinators on fruit set, Ent. Res. 45: 217-224. DOI: org/10.1111/1748-5967.12112

Blackman RL and Eastop VF (2000), Aphids on the world's crops: an identification and information guide, John Wiley and Sons Ltd. pp 1-476.
Cox JM (1989), The mealybug genus Planococcus (Homoptera: Pseudococcidae). Bull, British Musem. (Natl. Hist.), Ent. 58: 1-78.

Dhaliwal GS and Arora R (2001), Integrated Pest Management Concepts and Approaches. Kalyani Pulishers, New Delhi, India, pp 27-60.

FRG (Fertilizer Recommendation Guide) (2012). Bangladesh Agricultural Research Council, Farmgate, Dhaka, pp 179-184.

Islam MA, Amin MR, Rahman H, Yeasmin F and Haque ME (2019), Status of arthropod pests infesting different ornamental pests of Bangladesh, Bangladesh J. Ecol. 1: 11-15.

Katke M (2008), Seasonal incidence, biology and management of grape mealybug, Maconellicoccus hirsutus (Green) (Homoptera: Pseudococcidae). Doctoral Dissertation, UAS, Dharwad, pp 73-74.

Mandal E, Amin MR, Rahman $\mathrm{H}$ and Akanda MA (2018), Infestation level and population dynamics of aphid on mustard, Bangladesh J. Agril. Res. 43: 611-618. DOI: https://doi.org/10.3329/ bjar.v43i4.39160

Mohammad A, Alam SN, Mia MR U, Amin MR and Smriti RS (2019), Population fluctuation of jassid, and shoot and fruit borer of okra, Bangladesh J. Agril. Res. 44: 493-499. DOI: https://doi.org/10.3329/bjar.v44i3.43480

Namni S, Amin MR, Miah MRU, Rahman MF and Suh SJ (2017), Role of weather parameters on seasonal abundance of insects in a mango-based agroforestry in Bangladesh, with particular reference to mango hopper, Bangladesh J. Agril. Res. 42: 197-205.

Pal S and Sarkar I (2009), Pests infesting ornamental plants in hilly region of West Bengal, J. Plant Prot. Sci. 1: 98-101. 
Piron PG (2010), Appearance of Neotoxoptera formosana (Homoptera: Aphididae) in the Netherlands, Ent. Ber. 70: 10-12.

Reddy NA and Kumar CTA (2004), Insect pests of tomato, Lycopersicon esculentum Mill. in eastern dry zone of Karnataka, Insect Environ. 10: 40-42.

Reza M (2013), Flower Market Development in Bangladesh, BARC, Farmgate, Dhaka.

Saiyad MM (2015), Seasonal abundance, screening of genotypes and chemical control of gladiolus thrips, Thrips simplex (Morison). Ph.D. Dissertation, Navsari Agricultural University, Navsari, India. pp 41-42.

Sharma V and Singh BP (2012), Effect of varieties, seasons and weather on population buildup of leaf hopper (Amrasca devastans Distant) on potato crop, Potato J. 39: 23-30.

Sultana N (2003), Floriculture exports from Bangladesh. BARC, Farmgate, Dhaka. 